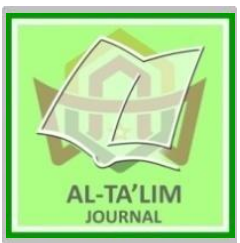

AL-TA'LIM JOURNAL, 26 (2), 2019, (191-205)

(Print ISSN 1410-7546 Online ISSN 2355-7893)

Available online at http://journal.TarbiyahUINib.ac.id/index.php/attalim

\title{
On Using of a Mobile Learning in Teaching History at UIN Imam Bonjol Padang: A Research and Development Model
}

\author{
Received: $05^{\text {th }}$ April2019; Revised: 06 $6^{\text {th }}$ June2019; Accepted: $30^{\text {th }}$ July 2019 \\ Permalink/DOI: http://dx.doi.org/10.15548/jt.v26i2.587
}

\section{Sasmi Nelwati*) \\ Universitas Islam Negeri Imam Bonjol \\ Padang, Indonesia \\ E-mail: sasminelwati@uinib.ac.id}

\section{Rezki Amelia}

STIT Padang Panjang, Indonesia

E-mail:rezkiamelia1987@gmail.com

\section{*) Corresponding Author}

\begin{abstract}
The study aims to develop a learning model through mobile learning in the Social Sciences Department of Tarbiyah Faculty of UIN Imam Bonjol Padang. This research is a developmental research. This research is aimed at developing a mobile learning model that is expected to be able to produce a product in the future. The product produced is in the learning development model through mobile learning in the Social Sciences Department of Tarbiyah Faculty of UIN Imam Bonjol Padang. Based on the results of the study, it was found that the development of learning models through mobile learning in the Social Sciences Department of History of the Faculty of Tarbiyah and Teacher Training at UIN Imam Bonjol Padang was effective in increasing students' interest in Social Sciences Department History and Development of practical learning models through mobile learning developed in Social Studies Department History of the Faculty of Tarbiyah and Teaching UIN Imam Bonjol Padang deserves to be developed in order to improve the quality and interest of students in the learning process.
\end{abstract}

Keywords: Mobile Learning; history; students' Competencies.

How to Cite: Nelwati, S., \& Amelia, R. (2019). On using of a mobile learning in teaching history at UIN Imam Bonjol Padang: A research and development model. Al-Ta Lim Journal, 26(2). doi:http://dx.doi.org/10.15548/jt.v26i2.587

\section{INTRODUCTION}

Education is one of the keysto improve a nation's civilization, the better the quality of education organized by a nation, the better quality of the community or the nation's resources will be. This condition leads to a high-value civilization based on the science. Education always responds to people's needs and challenges that arise among the community as a consequence of a change through education and teaching in formal and non-formal schools (Al Arifin, 2013; Dantes, 2007; Karsidi \& others, 2005; Sanaky, 2006; Sauri, 2007). The education that is able to support future development is an education that is able to develop the potential of students, so that the students are able to face and solve their problems (Ali, 2009; Tilaar, 1998). Education must be able to lay a hand on the potential of the conscience and potential competence of the students. The concept of education is important when the studentshave to participate in the community and the working world, because the students must be able to apply what they have learned in school to deal with the problems they faced in daily life today and in the future.

In the 21st century, the national education system faces a very complex 
challenge in preparing the quality of human resources (HR) that are able to compete in the globalization era. The proper effort to prepare the quality human resources and the only container that can be seen and as a tool to build high-quality human resources is through education. Therefore, in the current globalization era, it has penetrated into the world of education. It requires educational institutions to make various efforts oriented to the creation of graduate competencies that are globally competitive (Surakhmad \& Sularto, 2009). Sa'ud \& Sumantri (2007) related to the Commission on Education for the 21st Century recommends four strategies for the success of education: first, learning to learn, a process of learning to get to know regarding the acquisition, mastery and use of information in which today there is an explosion of information and knowledge. It is not only because of the very rapid developments in the field of science and technology, but also because of the rapid technological developments that allow large amounts of information and knowledge to be stored, can be obtained and disseminated quickly and almost reach the entire world; second, learning to be, contains the notion that learning is forming human beings who become themselves. In other words, learning to actualize themselves as individuals with thierown personalities who have responsibilities as human beings; third, learning to do, a learning is not just listening and seeing with the aim of accumulating knowledge, but learning to do with the ultimate goal of mastering competencies very much needed in the era of global competition; and fourth, learning to be together, which contains how learners are able to live in a society that is interdependent between each other, so that they can compete in a healthy manner and work together and be able to respect others.

Welcoming the age of Information and Communication Technology, the needs and interests must be improved by improving the learning quality(Ambarwaty, 2012; Anih, 2016; Elis Ratna Wulan, 2010; Hutfiyati, 2011; Ismuwardani \& others, 2006; Ritonga,
2015; Zainuddin, 2016). Through the use of information and communication technology, it will be able to improve the quality of human resources by opening wide access to science and the provision of quality education, especially the application of high tech dan high touch approach (Hasibuan, 2016; Nurdin, 2016). The role that can be given by this information technology application is to get information for personal life e.g. information about health, hobbies, recreation, and spirituality; and for professions e.g. science, technology, trading, business related news, and professional associations. The means of cooperation between one person and one group with another person or group without recognizing distance and time, country, race, economic class, ideology or other factors that can hinder the exchange of ideas.

It should also be realized that the development of information technology has entered various joints of life, including the world of education; especially learning has been intervened by the existence of this technology. Along with the development of information technology applications in the world of education, a variety of learning materials have also been produced and consumed by learners through the medium of information technology in the form of very varied packaging unlike the traditional learning process that relies on educators as the first and foremost learning resource while other sources are only complementary to learning activities.

Along with the development of information and communication technology that rapidly increase, it is allowing the learning process not only to be done in the classroom, but students can carry out the learning process anywhere and anytime. The learning process is greatly influenced by technological developments. This phenomenon will certainly strengthen, considering that the future technology will be more complex, powerful, and economically affordable. As the most popular example, the internet has become an important requirement 
for anyone involved in the learning process, both as a medium and as a learning resource. The same thing is also seen in mobile technology. The rapid development of mobile phone technology, both in terms of networks and devices, has caused this technology to develop very rapidly.

Sakat et al., (2012) state that learning using technology media has a significant influence on learning. Android devices are very close to the lives of students today, besides being a function of communication, android devices are also very potential to be developed into interactive learning media that are useful for students. Integrated technology in learning is one of the strategies to achieve learning goals because technology is no longer considered as a new thing. This is in accordance with the fact that the use of mobile devices (smartphones, PDAs or tablets) is already familiar among students. Most students have mobile phones that have more up to date features, so the development of learning models using Android is quite promising.

Thus mobile learning is able to make mobile phone that are originally only for texting, calling, or surfingto be a complete learning tool that contains lessons consisting of material, questions, sample questions, and try outs and equipped with various features such as search, jump to and back(Kusmana, 2011; Sambodo \& others, 2014). Putri, Huda, Ardiasih, \& Idrus (2013)said that Mobile learning is an alternative learning model that has unique characteristics that are not dependent on place and time. With cell phones app learning content can be packaged in a more fun and challenging form. Mobile learning is developed in a multimedia format that presents text, images, audio, and animation.

Mobile-Learning or M-learning is one of many implementations of the learning process in a modern way, where students can do learning whenever and wherever. MLearning is unique learning because students can access learning materials, directions and applications related to learning, anytime and anywhere through telecommunication devices such as mobile phones, smartphones, and tablets (Aditya, 2015). This will increase attention to the learning material, make learning become persuasive and can encourage students' motivation to lifelong learning. In addition, compared to conventional learning, M-Learning allows for more opportunities for collaboration and informal interaction among students.

Thus the concept of learning mobile learning is expected to encourage the realization of learning that is active, innovative, creative, effective, fun, joyful and weighty (pembelajaran yang aktif, inovatif, kreatif, efektif, menyenangkan, gembira dan berbobot - PAIKEM GEMBROT) (Matlubah, Anekawati, \& others, 2016; Rattu \& others, 2014). Because there are reasons that underlie the need for innovation or variation in learning that is the element of fatigue or boredom in humans even though students. Humans always want innovation or variety in various ways that cover their life needs including teaching and learning. Such an important thing is done by educators as the main driver of teaching and learning activities.

Based on the initial study conducted at the Social Sciences Department of Tarbiyah faculty at UIN Imam Bonjol Padang, the learning process that has taken place so far has not been fulfilled as stated in Goverment Regulation no. 19 of 2005. All this time the learning processes were conducted in classrooms with relatively large numbers of students. Lecturers teach in a class with around 35 to 50 students, even though the academic regulations state that a classroom should only hold a maximum of 40 students. This condition makes the lecturers have difficulty in managing the class interactively. In addition, facilities and the number of lecture hours are obstacles and limitations for educators to deliver material thoroughly. Furthermore, another fact was found that the learning processes conductedwere still less attractive to the students. It is because of lack of interest in the discussion offered, the implementation of discussions that have not 
been effective, and the lack of learning media used. The learning model used still uses conventional learning models that still cannot develop students' abilities perfectly. Plus learning in the Social Sciences Department is very broad in scope, a combination of elements of geography, history, economics, law and politics, citizenship, sociology, even in the fields of humanities, education and religion. With the breadth of coverage, sometimes there is a feeling of boredom when teaching by using the lecture method, discussion and question and answer. This is only from the side of the lecturer, not to mention from the student side as a learner. The heavy burden that must be carried out both by lecturers and students is certainly a factor of difficulty which inevitably has to be faced with and sought a solution. Therefore, the use of information technology in the learning process is needed so that boredom can be minimized and students will feel more comfortable when receiving teaching material.

To overcome these problems, the potential and prospects for the development of mobile learning in the future are very wideopen given the increasingly dynamic tendency of society and the demands of quality and diverse educational needs. This is in line with the Government Regulation No. 19 of 2005 which explained that learning is conducted in an inspiring, fun, challenging way to motivate students to actively participate, and provide sufficient space for initiatives, creativity, and independence in accordance with the talents, interests and physical and psychological development of students. The purpose of this study is to describe the vertical learning model through mobile learning in the Social Sciences Department and identify the feasibility of developing a practical learning model through mobile learning developed in the Social Sciences Department of Tarbiyah Faculty of UIN Imam Bonjol Padang.

\section{METHOD}

The type of research that fits the problem in this study is development research. This research aims at developing a mobile learning model that is expected to be able to produce a product in the form of a learning model that can be used in the learning process.

The research instruments developed to collect data in this study are questionnaires about aspects of assessment consisting of lecture material. Then the supporting component validation and display validation is carried out by learning design experts, content experts and curriculum experts. The validation sheet is compiled based on the instrument grid using a Likert scale. Another instrument is the questionnaire response of students using indicators that are simpler than the expert validation sheet. This is intended to adjust the assessment aspects of the cognitive development of students. Meanwhile, the data analysis technique used in this study is descriptive data analysis techniques.

\section{RESULTS AND DISCUSSIONS}

This research was conducted based on the results of observations conducted at Tarbiyah Faculty of UIN Imam Bonjol Padang which were the subjects of the study. It can be described that the procedures for implementing the learning conducted were largely systematic. In general, lecturers in teaching have taken the stages of learning: the preliminary stages, the core activities, and closing stages. The development of learning conducted by lecturers tended to be an expository approach whose indications were that lecturers were still dominant than students, there were still many lecturers in teaching social studies who explained subject matter rather than students so that the efforts to develop critical thinking skills and problem solving for students are still not implemented.

Then in the implementation of the material delivery some lecturers have already used media or teaching aids in the classroom, but there are some lecturers again explaining the material has not used the media, this is because there are several schools that still do not have complete facilities and infrastructure to support learning activities. Some schools 
already have media available at school but cannot function optimally in the learning process.

Based on the research that has been conducted, it can be seen that based on the observations, all students are able to understand entrepreneurial learning in financial aspects of entrepreneurial material presented in Android-based mobile learning media. In the aspect of software engineering students have a positive response where students ask to be made similar applications with different material. In the aspect of visual communication, students are able to understand the language used in this mobile learning model. There is no need to improve on this mobile learning media so that this model can be used for validation testing.

The development of this model consists of three stages: Define, Design,and Develop. The following will be elaborated on the development stage of the mobile learning model in the Social Sciences Department of Tarbiyah Faculty of UIN Imam Bonjol Padang as follows:

\section{Define}

Define or the defining stage is useful for determining and defining the needs in the learning process and collecting various information related to the products to be developed. The steps at the defining stage are as follows:

\section{Needs Analysis}

This needs analysis aims to identify the supporting and inhibiting factors of the learning process in order to select and determine the right and relevant models to achieve the learning objectives and lead to improving the quality of education. Needs analysis is intended to determine the needs or expectations students want to have, after the student completes an education level. This is done to anticipate a decrease in the quality of the qualifications that must be met. Needs analysis in this study is carried out by conducting a search of the learning process, the needs of students, and expectations that will be achieved through the learning process.
Thus, through this need analysis, the problem chosen is solved and the solution is sought by providing important information to determine suitable interventions.

\section{Curriculum analysis}

Curriculum analysis in this study was conducted to determine the development of the mobile learning model in the Meta Knowledge course. This course was developed and given to Social Sciences Education students of Tarbiyah Faculty of UIN Imam Bonjol Padang who later became professional teacher candidates so that by utilizing this model can create effective, efficient and purposeful learning. As prospective educators, students of Social Sciences Education are expected to be able to make and use understanding of maps properly and correctly so that the teaching experiences in the community can be enriched and more interesting and effective in accordance with the teaching objectives to be achieved.

This learning model uses two forms of learning strategies:face-to-face learning to get guidance and direction from the process of the material being taught, and students can also discuss with others about the material being taught. Then this model also combines with the independent and remote learning models commonly known as online learning models. So it is hoped that later with the merger of the lecture system can help students better understand the material they will learn and so that they can facilitate them to be able to apply independent learning, and also can learn anywhere, anytime. This is because the principles of mobile learning itself are: a) As asuplement (Suplemental): Mobile Learning functions as the supplement (Suplemental): students have the freedom to choose, whether to use Mobile Learning material or not. In this case, there is no obligation for students to access Mobile Learning material. Even though it is optional, students who use it will certainly have additional knowledge or insight. b) As a complement (Cmplemental): Mobile learning functions as a complement (complemental): the material is programmed 
to complement the learning material received by students in the classroom. Here means the material of Mobile Learning is programmed to become material reinforcement (reinforcement) or remedial for students in participating in conventional learning activities. Mobile Learning material is said to be enrichment, if students who can quickly master/understand the subject matter delivered by face-to-face educators (fast learners) are given the opportunity to access Mobile Learning material that is specifically developed for them. The goal is to further strengthen the level of mastery of students on the subject matter presented by educators in the classroom. It is said as a remedial program, if students who have difficulty understanding the subject matter presented by educators face to face in class, students who understand the material slowly (slowlearner) are given the opportunity to utilize Mobile Learning material that is specifically designed for them. The goal is for students to more easily understand the subject matter presented by educators in the class. c) As a substitution (Substitutional): Some universities in developed countries provide several alternative models of learning activities to their students. The goal is that students can flexibly manage their lecture activities in accordance with the time and daily activities of students. There are three alternative models of learning activities that can be chosen by students: 1) fully face-to-face (conventional), 2) partially face-to-face and partly through the internet, 3) entirely through the internet.

Any alternative learning model that will be chosen by students is not a problem in the assessment, because all models of presentation of performance material get the same recognition or assessment. If students can complete their lecture program and pass through conventional or fully methods through the internet, or through a combination of these two models, the education provider institution will give the same recognition. This very flexible situation is considered very helpful to accelerate the completion of his lectures.

\section{Learners Analysis}

Analysis of the characteristics of the students includes the actual abilities of the students, learning styles, attitudes toward learning activities. The activity of analyzing students can be done, for example by determining what students already know about the topic to be taught; sometimes students really do not realize or do not understand the knowledge of the subject being studied. Furthermore, they only understand some or misunderstandings about the topic. When lecturers teach, students can try to interpret what they understand and what they know from previous learning. They build new knowledge based on their previous understanding; therefore, it is very important for designers to determine the range and nature of previous student knowledge.

In this study, it is known that students who take courses in learning media are third semester students, because this course is a package from the Social Studies Education of Tarbiyah Faculty UIN Imam Bonjol Padang. The students studied in this study consisted of 36 students who had various characteristics. The students have major interest in cellphones is proven by the fsct that the students who have a cellphone is nearlyall (100\%). There are $90 \%$ of students who have cellphones with an android system, and $70 \%$ and $10 \%$ of students who have mobile phones that have access to material through the internet have standard mobile phones but they can access material via a computer by logging in to web provided. From this data it can be seen that they have a very high interest in mobile phones.In addition, students who were studied had different characteristics, especially in terms of learning styles, some of which were visual, audio, and kinesthetic. Therefore to meet the differences in learning styles, a combination of images, audio and video was carried out in terms of material design developed through this mobile learning model. Then the students who are the subjects of the study have high motivation for something beru in their learning process. And according to lecturers who are capable of 
class subjects, the authors make the subject of research highly motivated than other classes. Then in terms of student needs for innovation in learning, there is very little, therefore with this research they are very enthusiastic because they need a learning process that is flexible and can be done anywhere and anytime. And students need to present material that is different from usual.

\section{Design}

The designor designing stageaims to design a mobile-based learning model that can be used in social studies learning. This design phase includes: 1) Arranging criteria tests, as the first action to find out the initial abilities of students, and as an evaluation tool after the implementation of activities, 2) Selecting learning media that are in accordance with the material and characteristics of students, 3) Selection of customized learning presentation forms with the learning media used. If the educator will use audio-visual media, at the time of learning, of course students are told to see and appreciate the audio-visual media shows. 4) Simulate the presentation of material with the media and the learning steps that have been designed. At the time the learning simulation took place, the assessment was also conducted by the colleagues.

\section{Develop}

After conducting a needs analysis and the process of developing a mobile learning model was done. Develop or developing stageis conducted by paying attention to the components of learning namely syntax, social system, support system and reaction principle. At this stage the product of the Mobile learning model is made by using the appypie application. The steps taken are as follows: Before creating the learning media, first, we have to register at www.appypie.com. Application provider for making androidbased learning media for free but must be done online.
1. Accessing the web www.appypie.com

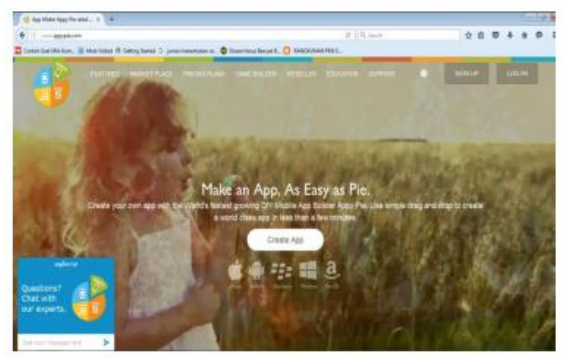

2. ClickSign up to sign.

3. Fill on the identity bars an then sign up.

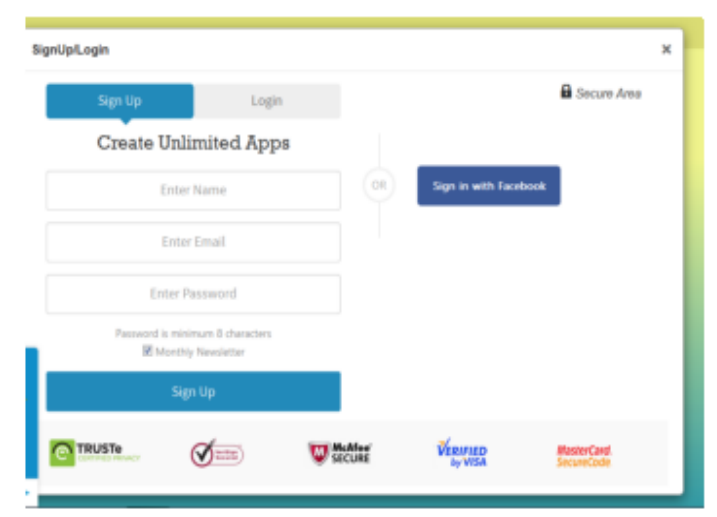

4. Buka kotak masuk pada gmail kemudian konfirmasi terlebih dahulu email dari appypie.

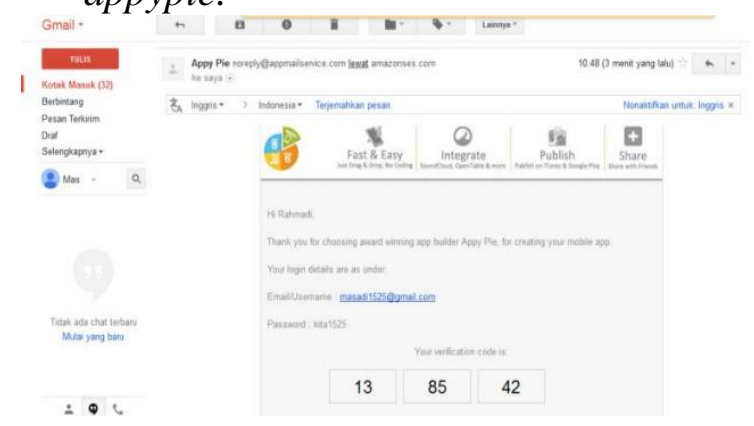

5. Enter the confirmation code that was sent via email and then click Verivy.

6. To create a new app, click create app
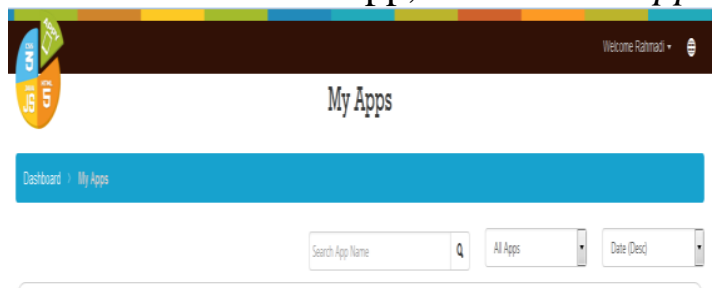

7. Select education, and select the type / cellphone platform on the right (android, iphone and others, fill in the name of the application to be created, then click next 


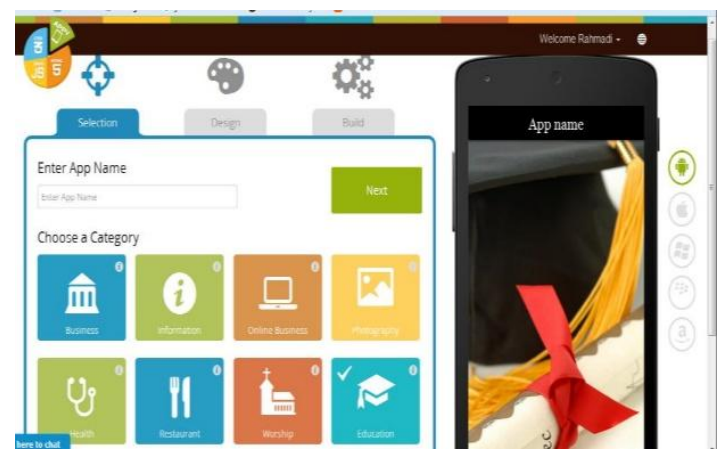

8. Pick the theme, clicknext

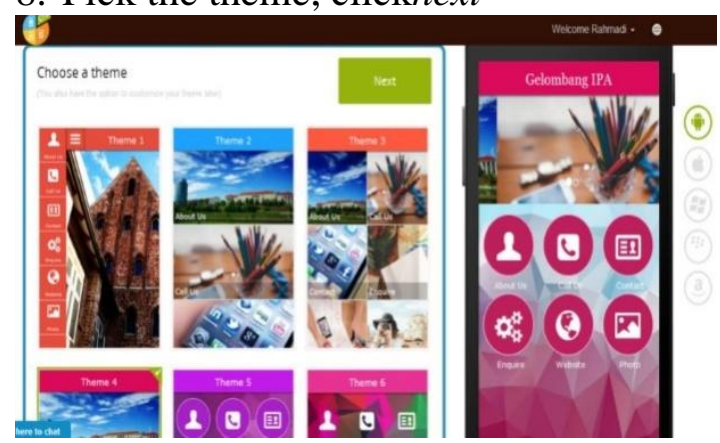

9. Fill in the page you want to write material.

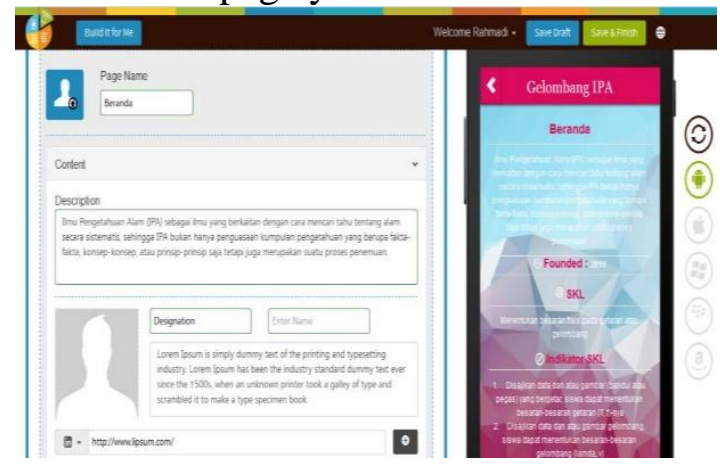

10. Pages that will not be used can be deleted, click on the morning then click the trash icon (delete), so the permission box appears, then click delete

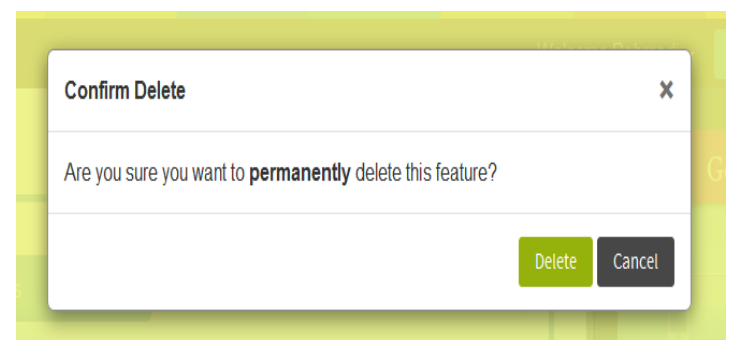

11. To add text or material, click add page, then select format textpage

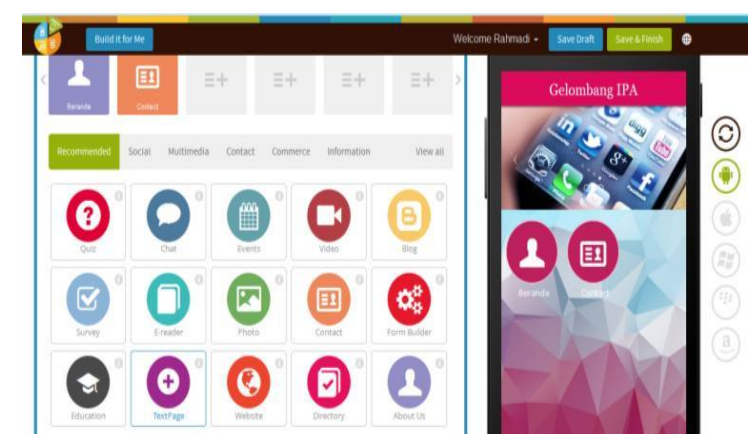

12. Fill the material ontextpage

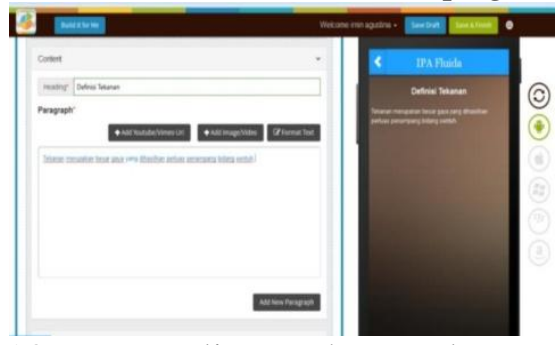

13. To adjust the color of the text, background, or banner click theme customization.

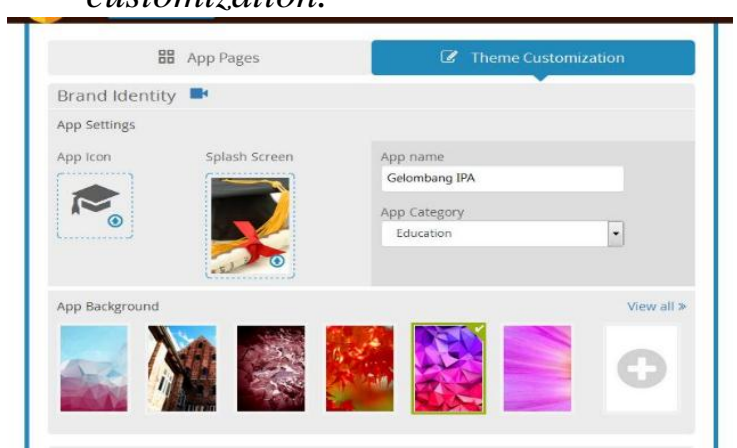

14. Click save draft in the upper right column. After completing the material, it would be better to save it first so that the product is not lost, and can be resumed if you want to add cotens or material at the next meeting.

15. After completing the content (contents) and settings then click save and finish, then it will appear as shown below. Then choose free and click subscribe now.

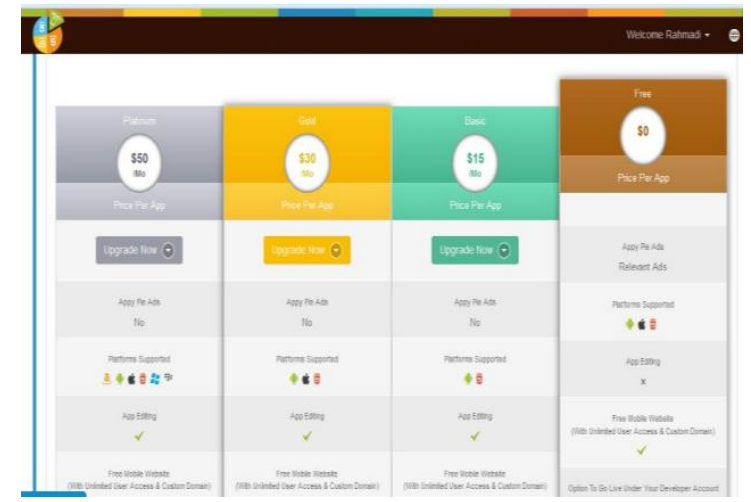


16. Click my app then click edit app, if all programs have finished waiting a few minutes, the application will be sent to email. After the application is sent, it can download the application whose format is .apk then it can be installed on the Android phone.

\section{Validation and Trial Stages}

\section{Design Validation Expert}

The results of the validity test conducted by design experts on the development of the mobile learning model, it can be seen that the percentage level of achievement of design experts is 85 in a very valid qualification. If it rests on the validator rating category, the achievement level 0-35 is invalid, the 40-45 achievement level is not valid, the 56-70 achievement level is quite valid, the 71-85 achievement level is valid, and the 85-100 achievement level is very valid, then the model component mobile learning is very valid.

\section{Material Validation Expert}

The results of the validity test conducted by material experts on the development of the mobile learning model, it can be seen that the percentage level of achievement of design experts is 76 in a very valid qualification. If it rests on the validator rating category, the achievement level 0-35 is invalid, the 40-45 achievement level is not valid, the 56-70 achievement level is quite valid, the 71-85 achievement level is valid, and the 85-100 achievement level is very valid, the model component of mobile learning is valid.

\section{Media Expert Validation}

The results of validity tests conducted by material experts on the development of the mobile learning model, it can be seen that the percentage level of achievement of design experts is 88 in a very valid qualification. If it rests on the validator rating category, the achievement level 0-35 is invalid, the 40-45 achievement level is not valid, the 56-70 achievement level is quite valid, the 71-85 achievement level is valid, and the 85-100 achievement level is very valid, then the model component mobile learning is very valid.

\section{Results of student responses to the model development}

Practical testing needs to be done to obtain information about the use of the mobile learning model. The practicality test answers whether the mobile learning model can be used or not. The practicality test was conducted on 36 students who took the MappingScience. Based on the student response questionnaire, it can be seen in the appendix.

Student learning outcomes in the Mapping Science which conducts lectures using the mobile learning model can be said that the assessment of 17 people is very effective because it is in the range of 85-100 achievement levels, while 15 people can be considered effective because the assessment is in the 71-85 achievement range.

\section{The development of a valid learning model through mobile learning in the Social Sciences Department - History, Tarbiyah Faculty, UIN Imam Bonjol Padang}

The development of the mobile learning model in this study is based on the results of the preliminary study and the lecture conditions in thesubject of Mapping Scienceof the Social Sciences Department History, Tarbiyah Faculty, UIN Imam Bonjol Padang, which aims to obtain a quality and enjoyable learning process, and enable the development of learning flexible for students then through this mobile learning model can also facilitate student learning wherever and whenever. Because it has characteristics that are practically carried anywhere, the mobile learning has its own interests. Along with developments in the mobile / mobile world with a variety of technological sophistication, many features are able to provide student and educational learning needs. Mobile Learning 
can also be utilized and developed in shaping a new learning culture that is more modern, democratic and educational. Culture of learning is a small part of the culture of society. Community culture is defined as the integration of all objects, ideas, knowledge, institutions, and ways of doing things, habits, and patterns of behavior, values, and attitudes of each generation in a society that are accepted by a generation of predecessors and continue to change to the next generation.

Another goal of developing mobile learning itself is a long life learning process, students can be more active in the learning process, saving time because when applied in the learning process students do not need to be present in the class just to collect assignments, enough sent via an application on a mobile phone which indirectly will improve the quality of the learning process itself. Likewise, if the lecturer cannot attend a lecturing course, one can use the m-learning system to deliver or send material or assignments. Increase the level of interaction between students and educators or enhance interactivity.

If carefully designed, mobile learning can increase the level of learning interactions, both between students and educators/instructors among fellow students, as well as between students and enhance interactivity unlike the case with conventional learning. Not all students in conventional activities can be brave or have the opportunity to raise questions or express their opinions in discussions. Usually this limited opportunity also tends to be dominated by some students who are responsive and brave. This situation will not occur in Mobile Learning. Students who are shy or who are hesitant or lack of courage have a wide opportunity to ask questions or express opinions without feeling watched or under pressure from classmates.

With an internet-connected mobile, it is definitely able to explore everything, including in finding teaching materials that support the learning process. The consideration of the effectiveness of mobilebased learning makes education practitioners to always offer the development of the latest models to help students and educators to be easier in learning at a minimum can provide student motivation to learn.

Based on the results of the validity test conducted by Design, material and media experts on the development of the mobile learning model, it can be seen that the percentage of achievement level of design experts is 85 , material experts are 92 and 88 media experts can be said to be in valid qualifications. If it rests on the validator rating category, the achievement level 0-35 is invalid, the 40-45 achievement level is not valid, the 56-70 achievement level is quite valid, the 71-85 achievement level is valid, and the 85-100 achievement level is very valid, the model component valid mobile learning value. Thus it can be said that the development of learning models using mobile learning can be used in the learning process.

\section{The development of a practical learning model through mobile learning in the Social Sciences Department - History, Tarbiyah Faculty,UIN Imam Bonjol Padang.}

Based on the practical tests that have been done, it can be seen that the mobile learning model can be applied because the practicality test is done to find out whether the model developed can be applied or not. Based on the tests conducted, it can be seen that the students' comments regarding the implementation of this model, especially in the syntax, stated the likes and wants of this model can also be applied to other subjects. Then from the student response, it can be seen that students do not experience difficulty in accessing the material provided on the cellphones, web and blog. According to them the instructions for use in the material provided are good and students are not bored reading it, the writing on the screen can also be easily read and the colors used to mix the dark and bright colors is done so there is no color gradient in the eyes. Then the learning process with this cellpone helps and facilitates them in understanding the material and 
pleasing them. Then students admit they are motivated to learn by using this model and by the way the lecturer gives them a wide opportunity to ask questions and express opinions. According to students, the presence of innovation in learning makes students able to increase their enthusiasm for learning and motivated to learn so students can be interested in what they will learn.

Then according to students learning by using this mobile is very pleasant but it needs to be considered the memory capacity used in designing the material that will be published via mobile phones, webs and blogs. Furthermore, the constraints faced by students during the learning process take place are because the appypie application is used using an online system so students suggest that there is an offline application because students are limited to the use of cellular data packages. In addition, students also suggested being able to apply learning models through learning cars with this app application can be applied to other subjects.

Based on practicality tests conducted on 36 students who took the Mapping Sciencesubject, it is known that student learning outcomes in the mapping Science subject which conducts lectures using the mobile learning model can be said that 17 people are very effective because they are in the 85-100 level range, while 15 people can be said to be effective because the assessment is in the 71-85 achievement range. Thus it can be concluded that learning using mobile learning is very practical to be applied in the learning process.

\section{CONCLUSIONS AND RECOMMENDATIONS}

The development of a realistic learning model through mobile learning in the Social Studies Department - History History, TarbiyahFaculty, UIN Imam Bonjol Padang was effective in increasing students' interest in Social Sciences Department - History. The development of a practical learning model through mobile learning developed at the Social Studies Department - History,
Tarbiyah Faculty, UIN Imam Bonjol Padang deserves to be developed in order to improve the quality and interest in learning.

In developing the vertical learning model through mobile learning in Social Studies Department - History, Tarbiyah Faculty, UIN Imam Bonjol Padang still has many things to develop, but there are some things that need to be developed. Therefore, it is suggested that the faculties must improve services to the development of IT and internet networks in all campus areas. Then, Lecturers must be more innovative to develop the process of learning apalgi by using IT media. Finally, students must be accustomed to using IT in the learning process.

\section{REFERENCES}

Aditya, H. F. (2015). Pengembangan Media Pembelajaran Berbasis Mobile Application Menggunakan Adobe Air For Android pada Mata Pelajaran Teknik Elektronika dan Jaringan untuk Siswa Kelas $\mathrm{X}$ Jurusan Rekayasa Perangkat Lunak Smk Ypkk 1 Sleman (UNY).

Al Arifin, A. H. (2013). Implementasi Pendidikan Multikulutral dalam Praksis Pendidikan di Indonesia. Jurnal Pembangunan Pendidikan: Fondasi Dan Aplikasi, 1(1).

Ali, M. (2009). Pendidikan untuk pembangunan nasional: Menuju bangsa Indonesia yang mandiri dan berdaya saing tinggi.

Ambarwaty, S. (2012). Membagun aplikasi pembelajaran berbasis multimedia interaktif menggunakan adobe flash CS3.

Anih, E. (2016). Modernisasi pembelajaran di perguruan tinggi berbasis teknologi informasi dan komunikasi memasuki abad 21. judika (jurnal pendidikan Unsika), 4(2). 
Dantes, N. (2007). Perspektif dan Kebijakan Pendidikan Menghadapi Tantangan Global.

Elis Ratna Wulan, E. (2010). Komunikasi dan Teknologi Informasi Pendidikan.

Hasibuan, N. (2016). Pengembangan Pendidikan Islam Dengan Implikasi Teknologi Pendidikan. Fitrah: Jurnal Kajian Ilmu-Ilmu Keislaman, 1(2), 189-206.

Hutfiyati, U. (2011). Pengaruh Kurikulum Berbasis Teknologi Informasi Dan Komunikasi (Tik) Terhadap Hasil Belajar Siswa Kelas Vii Pada Mata Pelajaran Pai Semester Genap Tahun Pembelajaran 2010/2011 Di Smp Negeri I Magetan (UIN Sunan Ampel Surabaya).

Ismuwardani, W., \& others. (2006). Pembelajaran Teknologi Informasi dan Komunikasi (TIK) Oleh GuruGuru SMA Negeri Se-Kabupaten Kendal dalam Pelaksanaan Kurikulum 2006. Universitas Negeri Semarang.

Karsidi, D., \& others. (2005). Sosiologi Pendidikan.

Kusmana, A. (2011). E-learning dalam Pembelajaran. Lentera Pendidikan, 14(1), 35-51.

Matlubah, H., Anekawati, A., \& others. (2016). Aplikasi Mobile Learning Berbasis Smartphone Android Sebagai Sumber Belajar Mahasiswa Program Studi Pendidikan Ipa Universitas Wiraraja Sumenep. Lensa (Lentera Sains), 6(2).

Nurdin, A. (2016). Inovasi Pembelajaran Pendidikan Agama Islam Di Era Information And Communication Technology. Tadris: Jurnal Pendidikan Islam, 11(1), 49-64.

Putri, D. A. P., Huda, N., Ardiasih, L. S., \& Idrus, O. (2013). Pemanfaatan Pembelajaran Mobile Di Indonesia
Dan Arah Perkembangannya Di Masa Mendatang.

Rattu, N. N., \& others. (2014). Perbedaan Self Regulation Learning antara Mahasiswa yang Menggunakan Smartphone dan yang Tidak Menggunakan Smartphone di Fakultas Psikologi Universitas Kristen Satya Wacana (Program Studi Psikologi FPSI-UKSW).

Ritonga, D. I. (2015). Isu-Isu Kritis Dalam Pendidikan Mengenai Kompetensi Guru/Dosen Pada Abad 21. Bahas, 26(2).

Sakat, A. A., Zin, M. Z. M., Muhamad, R., Ahmad, A., Ahmad, N. A., \& Kasmo, M. A. (2012). Educational technology media method in teaching and learning progress. American Journal of Applied Sciences, 9(6), 874.

Sambodo, R. A., \& others. (2014). Pengembangan Media Pembelajaran Mobile Learning (m-learning) Berbasis Android untuk Siswa Kelas XI SMA/MA (UIN SUNAN KALIJAGA).

Sanaky, H. A. (2006). Paradigma Pembangunan Pendidikan di Indonesia Pasca Reformasi antara Mitos dan Realitas. Dalam Jurnal Ilmuilmu Sosial Unisia, 62.

Sa'ud, U. S., \& Sumantri, M. (2007). Pendidikan Dasar dan Menengah. Ilmu Dan Aplikasi Pendidikan Bagian 4 Pendidikan Lintas Bidang.

Sauri, S. (2007). Sekilas tentang Pendidikan Nilai. Makalah Yang Disajikan Dalam Kegiatan Pelatihan Guru-Guru Di Kampus Politeknik UNSI Kabupaten Sukabumi Pada Tanggal, 29.

Surakhmad, W., \& Sularto, S. (2009). Pendidikan nasional, strategi, dan tragedi. 
Tilaar, H. A. R. (1998). Beberapa agenda reformasi pendidikan nasional dalam perspektif abad 21.

Zainuddin, A. S. (2016). Persepsi dan Implementasi Kebijakan Teknologi Informasi Dan Komunikasi Sebagai
Sarana Pembelajaran dan Pengaruhnya Terhadap Peningkatan Kualitas Pendidikan Pada SMA Negeri Kota Pematang Siantar. Jurnal Administrasi Publik: Public Administration Journal, 3(1). 